\title{
Process Regulation in the Problem-Solving Processes of Fifth Graders
}

BENJAMIN RotT ${ }^{1}$

$\approx$ It is well known that the regulation of processes is an important factor in problem solving from Grade 7 to university level (cf. Mevarech \& Kramarski, 1997; Schoenfeld, 1985). We do not, however, know much about the problem-solving competencies of younger children (cf. Heinze, 2007, p. 15). Do the results of studies also hold true for students below Grade 7 ? The study presented here strongly suggests that metacognition and process regulation is important in Grade 5 as well.

The research questions are: How do the (more or less successful) problem-solving processes of fifth graders occur? What is the impact of metacognition and selfregulation on these processes? Are the transitions between phases in the problemsolving process closely connected to metacognitive activities?

An analysis of approximately 100 problem-solving processes of fifth graders (aged 10-12) from German secondary schools will be used to help answer these questions. The videotapes that supplied the raw data were parsed into phases called episodes using an adapted version of the "protocol analysis framework" by Schoenfeld (1985, ch. 9). The junctures between these episodes were additionally coded with the "system for categorizing metacognitive activities" by Cohors-Fresenborg and Kaune (2007a). There is a strong correlation between (missing) process regulation and success (or failure) in the problem-solving attempts.

Concluding suggestions are given for the implementation of the results in school teaching. These suggestions are currently being tested.

Keywords: Control; Mathematical problem solving; Metacognition; Process regulation 


\section{Usmerjanje procesov reševanja problemov petošolcev}

BENJAMIN RotT

$\propto$ Znano je, da je usmerjanje procesov pomemben dejavnik pri reševanju problemov - od 7. razreda do univerzitetne ravni (Mevarech \& Kramarski, 1997; Schoenfeld, 1985). Malo pa vemo o kompetencah reševanja problemov pri mlajših otrocih (Heinze, 2007, str. 15). Ali izsledki teh študij veljajo tudi za učence nižjih razredov? Predstavljena raziskava močno nakazuje pomen metakognicije in usmerjanja procesov tudi v 5 . razredu. Raziskovalna vprašanja so: Kako (bolj ali manj uspešno) poteka postopek reševanja problemov petošolcev? Kakšen je vpliv metakognicije in samoregulacije na te postopke? Ali so prehodi med fazami procesa reševanja problemov tesno povezani $\mathrm{z}$ metakognitivnimi dejavnostmi? Analiza približno stotih postopkov reševanja problemov petošolcev (starih od 10 do 12 let) iz nemških osnovnih šol lahko pomaga pri odgovorih na ta vprašanja. Posnetki z videokaset, ki so podali neobdelane podatke, so bili z uporabo prilagojene različice Schönfeldovega "protokola analize podatkov« razčlenjeni v faze, imenovane epizode (1985, poglavje 9). Stičišča med temi epizodami so bila dodatno kodirana $\mathrm{z} »$ merili $\mathrm{za}$ razvrščanje metakognitivnih aktivnosti« avtorjev Cohors - Fresenborg in Kaune (2007a). Obstaja močna povezava med (manjkajočim) usmerjanjem procesov in uspehom (ali neuspehom) pri reševanju problemov. Podani so sklepni predlogi za uvajanje izsledkov naše raziskave v šolski pouk.

Ključne besede: matematično reševanje problemov, metakognicija, usmerjanje procesov 


\section{Background}

Problem solving is important in everyday life, in situations where the solution path is not immediately obvious (cf. OECD, 2003), as well as in mathematics, because "what mathematics really consists of is problems and solutions" (Halmos, 1980, p. 519). It is widely accepted that solving problems is of importance for the learning of mathematics, and it is therefore part of many school curricula, e.g., in the United States and Germany (cf. KMK, 2003; NCTM, 2000).

In researching problem-solving, metacognition is an important factor to take into account (with resources, heuristics and beliefs being other factors, cf. Schoenfeld, 1985, p. 44 f.). According to Flavell (1976, p. 232), who was the first to describe this concept, the term metacognition "refers to one's knowledge concerning one's own cognitive processes and products or anything related to them, [...]. [It] refers, among other things, to the active monitoring and consequent regulation and orchestration of these processes [...]".

The theoretical impact of metacognition: The latter part of Flavell's description, self-regulation or control, "deals with the question of resource management and allocation [...]" (Schoenfeld, 1985, p. 44 f.). The importance of self-regulation is highlighted in several models of the problem-solving process, some of which are presented in the following paragraphs.

Schoenfeld (1985, ch. 4), for example, describes design within problem solving as "something that pervades the entire solution process; its function is to ensure that you [as a problem solver] are engaged in activities most likely ([...]) to be profitable. Most generally, it means keeping a global perspective on what you are doing and proceeding hierarchically" (ibid., p. 108). Furthermore, Schoenfeld (1985, p. 300) claims that the transitions between phases in the problem-solving process are places "where managerial decisions (or their absence) will make or break a solution".

Mason, Burton, and Stacey (2010, ch. 7) suggest listening to an internal monitor that might guide a problem solver to go back to a planning step ("Attack") in his/her process, or to choose another strategy for the problem.

Finally, Wilson, Fernandez, and Hadaway (1993) claim that each movement from one (Pólya-like) stage to another in a problem-solving process represents a managerial decision.

The empirical impact of metacognition: There are also several studies that demonstrate the impact of self-regulation on the performance of problemsolving attempts. Schoenfeld (1992, p. 63), for instance, worked with university students and analysed their problem-solving processes. Approximately 60\% 
of the students showed a behaviour that Schoenfeld called "wild goose chase", whereby the students picked a solution direction and pursued it until they ran out of time, without reflecting on it. After a problem-solving course in which he regularly asked the students three questions - "What exactly are you doing?", "Why are you doing it?", and "How does it help you?" - the percentage of students not regulating their processes was reduced to $20 \%$, accompanied by a proportional increase in the success of their problem-solving attempts.

Working with school students, Lester, Garofalo, and Kroll (1989, p. 115) obtained the following results in a study with two Grade 7 classes: "In general, it seems that the more successful problem solvers in our study were better able to monitor and regulate their problem-solving activity than the poorer problem solvers [...]. This observation is, of course, consistent with the preponderance of the research on expert-novice problem solving [...]"

Mevarech and Kramarski (1997) also worked with Grade 7 students, divided into two groups. The students in the experimental group (three classes), who had undergone metacognitive and self-regulatory training, showed significantly better results in mathematics tests than those in the control group (five classes).

A collection of several studies on metacognition is presented by CohorsFresenborg, Kramer, Pundsack, Sjuts, and Sommer (2010). All of these studies show a positive correlation between metacognitive behaviour and success in problem solving. Most notably, those high school students who demonstrated metacognitive activities ${ }^{2}$ in problem-solving interviews scored significantly better results in a written mathematics test (cf. ibid., p. 234 ff.) than those who did not.

The research gap: As stated above, although we know the impact of metacognition and regulation on the problem-solving processes of students of Grade 7 onwards, we do not know much about the problem-solving abilities and processes of younger children, as there is a lack of research (cf. Heinze, 2007, p. 15). I therefore raise the following research questions:

- How do the (more or less successful) problem-solving processes of fifth graders occur?

- What is the impact of metacognition and self-regulation on these processes?

And, with the theoretical models (described above) in mind:

- $\quad$ Are the transitions between phases in the problem-solving process closely connected to metacognitive activities?

2 The activities were coded within the framework by Cohors-Fresenborg and Kaune (2007a), which is described in the Methodology section (see below). 


\section{Design of the study}

Our support and research programme $\mathrm{MALU}^{3}$ was an enrichment project for interested fifth graders (aged 10-12) from secondary schools in Hanover in Northern Germany. From November 2008 to June 2010, pupils came to our university once a week. A group of 10-16 children (45 altogether in four terms) was formed every new term. The sessions usually proceeded according to the following pattern. After some initial games and tasks, the pupils worked in pairs on 1-3 mathematical problems (about 30 different tasks in all) for about 40 minutes, during which time they were videotaped. They eventually presented their results to the whole group. The children's notes were also collected.

The pupils worked on the problems without interruptions or hints from the observers, because we wanted to study their uninfluenced problem-solving attempts. We decided not to use an interview or a think-aloud method, so as not to interrupt the students' mental processes. In order to gain an insight into their thoughts, we let the children work in pairs, thus providing an opportunity to interpret their communication as well as their actions.

In Tables 1 and 2, there are two examples of the problems we posed, four of which have been selected for analyses in the present paper (see Rott, 2012a for more examples).

Table 1. The coasters task (idea: Schoenfeld, 1985, p. 77).
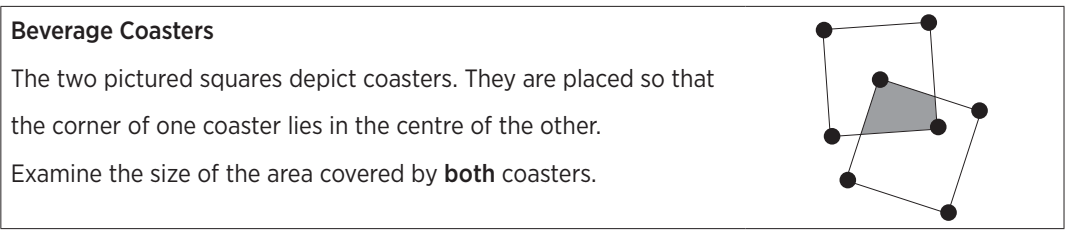

Table 2. The chessboard task (idea: Mason, Burton, \& Stacey, 2010, p. 17)
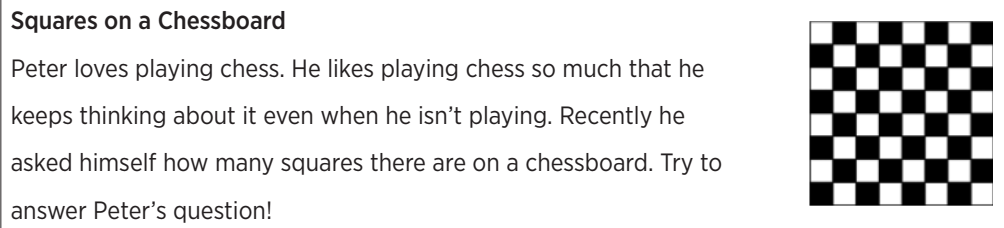

3 Mathematik AG an der Leibniz Universität, which means Mathematics Working Group at Leibniz University. 


\section{Methodology}

Product Coding: In order to determine the pupils' success in problem solving, their work results were graded into four categories: (1) no access, when the pupils did not work on the task meaningfully, (2) basic access, when they solved (parts of) the problem but the solution had notable flaws, (3) advanced access, when they solved the problem for the most part, and (4) full access, when the pupils solved the task properly and presented appropriate reasons.

This grading system was customised for each task with examples for each category (see Rott, 2012a for examples). All of the products were then rated independently by the author and a research assistant. We agreed in almost all cases (Cohen's kappa>0.9) and discussed the few differing ratings, reaching consensus every time. These discussions also led to better defined categories. It is important to note that the two members of a pair of problem solvers could, and sometimes did, achieve diverse ratings of their products when their written results differed.

Process Coding - Episodes: The pupils' behaviour was coded using the framework for the analysis of videotaped problem-solving sessions presented by Schoenfeld (1985, ch. 9). His intention was to "identify major turning points in a solution. This is done by parsing a protocol into macroscopic chunks called episodes [...]" (ibid., p. 314). An episode is "a period of time during which an individual or a problem-solving group is engaged in one large task [...] or a closely related body of tasks in the service of the same goal [...]" (ibid., p. 292). Schoenfeld (1992, p. 189) continues: "We found [...] that the episodes fell rather naturally into one of six categories:"

(1) Reading or rereading the problem.

(2) Analyzing the problem (in a coherent and structured way).

(3) Exploring aspects of the problem (in a much less structured way than in Analysis).

(4) Planning all or part of a solution.

(5) Implementing a plan.

(6) Verifying a solution.

We adopted this framework for our study with the following modifications. We initially experienced some difficulties in coding reliably (as predicted by Schoenfeld, 1992, p. 194). We therefore operationalised Schoenfeld's framework, which is constructed based on Pólya's famous list of questions and guidelines, by applying Pólya's suggestions to the episode descriptions (see Rott, 2012a for details). 
Secondly, we added new categories of episodes, because our fifth graders unlike university students - demonstrated plenty of non-task-related behaviour. (7) Digression, when pupils show no task-related behaviour at all.

(8) Organisation, when working on the task is being prepared or followed up, e.g., by drawing lines to write on or by filing away worksheets.

(9) Writing, when pupils captured their results without gaining new insights.

(10) Miscellaneous - behaviour that is not covered by any other type of episode.

For the analyses presented in the present paper, only the task-related episodes are relevant, i.e., (2) - (6) of Schoenfeld's list.

This framework was used to code all of the MALU processes (see the Appendix for a sample coding). This coding was done independently by research assistants and the author. In order to compute the interrater-reliability, we applied the "percentage of agreement" approach as described in the TIMSS 1999 video study (cf. Jacobs et al., 2003, p. 99 ff.) for randomly chosen videos, gaining more than $\mathrm{PA}=0.7$ for the parsing into episodes and more than $\mathrm{PA}=0.85$ for the characterisation of the episode types. More importantly, however, each process was coded by at least two raters. Whenever these codes did not coincide (most of the time they did coincide), we attained agreement by recoding together (cf. Schoenfeld, 1992, p. 194).

Process Coding - Metacognitive Activities: The occurrence of metacognition should also have been coded in our pupils' processes. Schoenfeld (1985) included "local" and "global" assessments in his framework, local assessment being "an evaluation of the current state of the solution at a microscopic level" (ibid., p. 299). Unfortunately, in our team we were not able to use this description and Schoenfeld's examples to code assessments reliably.

Instead, we used another framework: Cohors-Fresenborg and Kaune (2007a; see 2007b for an English description) developed a "system for categorizing metacognitive activities during [...] mathematics lessons" (2007b, p. 1182). There are three categories - planning $(\mathbf{P})$, monitoring $(\mathbf{M})$ and reflection (R) (as well as discursivity, which is not significant to our study) - to apply to passages in the transcript of a lesson, with subcategories such as "M1: Controlling of Calculation", "M8: Self-Monitoring" or "R1: Reflection on Concepts". Some of these subcategories also have specifications like "P1: Focus of attention" - "P1a: single-step" and "P1b: multi-step".

We adapted this system to identify metacognitive activities in our twoperson problem-solving processes and used this framework to code some of our pupils' problem-solving processes (see the Appendix for a sample coding). 
All of the processes were coded conjointly by three raters and discussed until all of the raters reached consensus, as described in the manual (cf. CohorsFresenborg \& Kaune, 2007a).

\section{Results}

The results shown here combine the analyses of all of our pupils' processes working on four different tasks (for details, see Rott, 2012a). Please note that 10 of the 19 pupils who worked on the "Squares on a Chessboard" task misinterpreted the formulation of the task and answered " 64 squares" within less than 3 minutes. This is a sure sign of missing metacognition or control that leads to bad results. These processes were excluded from the following analyses, as the children just followed routine patterns instead of showing problem-solving behaviour, whereas the focus of the present article is on control in problem-solving processes.

Wild Goose Chases: After dividing all of the processes into episodes to see how our pupils' processes occur, the codes had to be analysed. One of Schoenfeld's major findings, obtained with his video analysis framework, was the accentuation of the importance of metacognitive and self-regulatory activities in problem-solving processes. Problem solvers who missed out on such activities often engaged in a behaviour that Schoenfeld called "wild goose chase" (see above), whereas "successful solution attempts [...] consistently contained a significant amount of self-regulatory activity" (Schoenfeld, 1992, p. 195).

Most of the unsuccessful processes of our pupils did in fact demonstrate behaviour that fits the description of "wild goose chase" (most notably, these processes consisted almost exclusively of long Exploration episodes). In order to apply Schoenfeld's result to the MALU data, we had to operationalise the problemsolving type "wild goose chase", as he provided no real definition of it. In his book, Schoenfeld (1985, p. 307) denotes this type of behaviour as the "read/explore type". Thus, a process is considered to be a "wild goose chase" if it consists only of Exploration episodes. ${ }^{4}$ It is possible, however, that pupils try to understand the task given to them for a short time before selecting a solution direction and pursuing it thoughtlessly. Accordingly, processes were also considered to be a "wild goose chase" if they consisted only of Analysis \& Exploration episodes, ${ }^{5}$ whereas processes that were not of this type mostly contained planning and/or verifying activities.

In order to check whether this kind of behaviour in the processes is interrelated with success or failure of the related products, a chi-square test was

4 I concentrate on the task-related episodes, disregarding Reading and the added types of episodes (see the Methodology section).

5 In our sample, there were no "wild goose chase" candidates in which the Analysis was nearly as long as the Exploration, thus we did not need to deal with the duration of the Analysis episodes. 
used. The null hypothesis is "no correlation between the problem-solving type 'wild goose chase' and (no) success in the product". Due to the small size of the database, the product categories had to be subsumed by twos, to "no \& basic approach" as well as "advanced and full access".

The entries in Table 3 consist of the observed numbers, while the expected numbers (calculated by the marginal totals) are added in brackets. The entries in the main diagonal are apparently above the expected values. The chi-square-test shows a significant correlation $(\mathrm{p}<0.001)$ between the problem solvers' behaviour and their success.

Table 3. Contingency table - process behaviour and product success (10 of the 19 processes belonging to the "Squares on a Chessboard" task have been excluded from these data).

\begin{tabular}{cccc}
\hline process / product categories & no \& basic access & advanced \& full access & sum \\
\hline wild goose chase & $27(15.6)$ & $5(16.4)$ & 32 \\
miscellaneous & $16(27.4)$ & $40(28.6)$ & 56 \\
sum & 43 & 45 & 88 \\
\hline$\chi^{2}=25.378$ & $p<0.0001$ & Yates- $p<0.0001$ & 12 \\
\hline
\end{tabular}

These results show the huge importance of self-regulation and processregulation during problem-solving attempts. Wild goose chases imply missing changes between episodes and thus missing process regulation. Schoenfeld (1985, p. 300) emphasises that especially the "junctures between episodes [are parts], where managerial decisions (or their absence) will make or break a solution". This claim is in line with other models of the problem-solving process, e.g., Schoenfeld's (1985, ch. 4) "design", the "internal monitor" by Mason, Burton, and Stacey (2010, ch. 7), or the "managerial decisions" that are part of each transition between Pólya-like problem-solving phases by Wilson, Fernandez, and Hadaway (1993) (see Rott, 2012b for a comparison of these models).

Junctures between episodes: The result of the chi-square-test (see Table 3) and especially the theoretical assumptions of the models of the problem-solving process (see above), suggest the need for further investigation of the processes of our pupils, concentrating on the junctures between episodes. Are the transitions between phases in the problem-solving process closely connected to metacognitive activities? (research question 3 )

Approximately $25 \%$ of the processes analysed with Schoenfeld's schema were additionally and independently coded with the system by Cohors-Fresenborg and Kaune. In almost all cases, the junctures between episodes also showed metacognitive activities - mostly "P1: Focus of Attention" and "R6: Reflective 
Assessment / Evaluation" (see the Appendix for an example). This supports the theoretical assumptions, as well as highlighting the importance of metacognition and self-regulation during problem solving. The occurrence of mostly two codes (of about twenty different codes) should be explored further in subsequent studies.

\section{Conclusions and implications}

Self-regulation and process-regulation are very important factors in problem solving. In the present study, the junctures between (Pólya-like) episodes in problem-solving processes are closely related to metacognitive activities. Pupils who missed changing episode types (especially those who mostly conducted an Exploration episode, thus performing a "wild goose chase") regulated their processes badly. These pupils were significantly less successful than the pupils who did not show "wild goose chase" behaviour.

The sample of pupils used to obtain these results is not representative, as the children all came to our university voluntarily to participate in mathematical activities. Nonetheless, the results are in line with those of several studies that have consistently shown the importance of control and regulation (e.g., CohorsFresenborg et al., 2010; Lester, Garofalo, \& Kroll, 1989; Mevarech \& Kramarski, 1997; Schoenfeld, 1992), thus adding to the validity of the present study.

Fortunately for those pupils who performed badly, self-regulatory behaviour is learnable and can be taught, as has been demonstrated several times (e.g., by Schoenfeld, 1992 or Mevarech \& Kramarski, 1997, see above). As an impetus for future studies, and following from our results in the classroom, I would like to present a training programme fostering students' self-regulation.

In our working group, we tried the following procedure. In addition to a two-column proof schema, Brockmann-Behnsen (2012a, b) used a set of questions similar to those of Schoenfeld (1992, see above) to help students to foster metacognitive activities. He let the students of his experimental classes regularly pose two questions whenever they tried to solve problems or to reason in a mathematical sense. However, unlike Schoenfeld, Brockmann-Behnsen used a model suitable for children: Imagine, in a mathematical argumentation, you have to pass two gates, each one with a guardian that lets you pass only if you can answer his question: 1. Why are you allowed to do it? and 2. How does it help you?

The initial results of a small training study - admittedly, not with fifth graders - using these two questions seem to be very promising. A short pre-test (a

6 The German versions of these questions are "1. Warum darfst Du das?” and "2. Was bringt es Dir?" 
geometric reasoning task) showed no significant differences between a set of four eighth grade classes (children aged 13-15). However, a post-test (using a comparable, slightly more difficult problem) after six weeks of training for two of those classes indicated significant differences in favour of the experimental groups. The control groups did not show any change in their level of success (mostly no success) or in the structure of their reasoning (mostly incoherent arguments). The experimental groups, on the other hand, displayed clear improvements in achieving correct solutions and in using mostly coherent, deductive reasoning.

Training programmes like the one presented by Brockmann-Behnsen should be extended to other age groups (such as fifth graders) and monitored scientifically. Additional video studies could analyse the students' behaviour with a focus on wild goose chases.

Related research intent would include a closer examination of possible correlations between the use of metacognitive activities (in general or special activities) and success in problem-solving attempts. Cohors-Fresenborg et al. (2010) present some studies that indicate such a correlation (see above). In particular, students who had shown a special kind of monitoring in a problemsolving interview were more successful in a written test: "M8f: Self-Monitoring of Monitoring", a meta-meta-category that supervised the use of monitoring in processes. In studies like the one presented in the present paper, it could be investigated whether there are similar special categories of metacognitive activities, or whether there is a general correlation to success.

On the theoretical side, the question as to whether junctures between phases (or episodes respectively) in the problem-solving process are (almost) always connected to metacognitive activities should be further explored. Personally, I have no knowledge of other studies that have independently coded and compared problem-solving phases and occurrences of metacognition.

\section{References}

Brockmann-Behnsen, D. (2012a). HeuRekAP - Erste Ergebnisse der Langzeitstudie zum Problemlösen und Beweisen am Gymnasium. In M. Ludwig \& M. Kleine (Eds.), Beiträge zum Mathematikunterricht 2012. Münster: WTM.

Brockmann-Behnsen, D. (2012b). A long-term educational treatment using dynamic geometry software. In M. Joubert, A. Clarck-Wilson, \& M. McCabe, Proceedings of the 1oth International Conference for Technology in Mathematics Teaching (ICTMT1o) (pp. 196-302).

Cohors-Fresenborg, E., \& Kaune, C. (2007a). Kategoriensystem für metakognitive Aktivitäten beim schrittweise kontrollierten Argumentieren im Mathematikunterricht. Arbeitsbericht Nr. 44, Forschungsinstitut für Mathematikdidaktik, Universität Osnabrück. 
Cohors-Fresenborg, E., \& Kaune, C. (2007b). Modelling Classroom Discussions and Categorising Discursive and Metacognitive Activities. In Proceedings of CERME 5 (pp. 1180 - 1189). Retrieved December 212012 from http://www.ikm.uni-osnabrueck.de/mitglieder/cohors/literatur/CERME5_ discursivness_metacognition.pdf

Cohors-Fresenborg, E., Kramer, S., Pundsack, F., Sjuts, J., \& Sommer, N. (2010). The role of metacognitive monitoring in explaining differences in mathematics achievement. ZDM Mathematics Education, 42, 231-244.

Jacobs, J., Garnier, H., Gallimore, R., Hollingsworth, H., Givvin, K. B., Rust, K., et al. (2003).

Third International Mathematics and Science Study 1999 Video Study Technical Report. Volume 1:

Mathematics. Washington: National Center for Education Statistics. Institute of Education Statistics,

U. S. Department of Education.

Mason, J., Burton, L., \& Stacey, K. (1982/2010). Thinking Mathematically. Dorchester: Pearson Education Limited. Second Edition.

Mevarech, Z. R., \& Kramarski, B. (1997). IMPROVE: A Multidimensional Method for Teaching

Mathematics in Heterogeneous Classrooms. American Educational Research Journal, 92(4), 365-394. Pólya, G. (1945). How to Solve It. Princeton, NJ: University Press.

Rott, B. (2012a). Problem Solving Processes of Fifth Graders - an Analysis of Problem Solving Types. In Proceedings of the 12th ICME Conference. Seoul, Korea. Retrieved November 252012 from http:// www.icme12.org/upload/UpFile2/TSG/o291.pdf

Rott, B. (2012b). Models of the Problem Solving Process - a Discussion Referring to the Processes of Fifth Graders. In T. Bergqvist (Ed.), Proceedings from the $13^{\text {th }}$ ProMath conference, Sep. 2011 (pp. 95-109).

Schoenfeld, A. H. (1985). Mathematical Problem Solving. Orlando, Florida: Academic Press, Inc. Schoenfeld, A. H. (1992). On Paradigms and Methods: What do you do when the ones you know don't do what you want them to? Issues in the Analysis of data in the form of videotapes. The Journal of the learning of sciences, 2(2), 179-214.

Wilson, J. W., Fernandez, M. L., \& Hadaway, N. (1993). Mathematical problem solving. In P. S. Wilson (Ed.), Research ideas for the classroom: High school mathematics. Chapter. 4. (pp. 57-77).

\section{Biographical note}

BENJAMin RotT attended the University of Oldenburg to become a secondary teacher for mathematics and physics; his thesis was on the topic of problem solving and dynamic geometry software. His studies were followed by a two-year teacher training at a school near Braunschweig to gain a full teaching license. Starting at the end of 2008 , he wrote his $\mathrm{PhD}$ thesis on the topic of mathematical problem solving at the University of Hanover, which he defended in 2012. Since then, he works at the University of Education Freiburg as a postdoctoral researcher on the topic of epistemic beliefs. 


\section{Appendix}

$\mathrm{L}$ and $\mathrm{E}$ are two girls working on the "Squares on a Chessboard" task. The codes in the last column refer to the coding of metacognitive activities by Cohors-Fresenborg and Kaune (2007a, b).

Table 4. $L \& E$ - Squares on a Chessboard-excerpt from the transcript, part 1 of 2.

\begin{tabular}{|c|c|c|c|}
\hline time & $\mathrm{L}$ & $\mathrm{E}$ & commentary, codes \\
\hline $00: 27$ & $\begin{array}{l}\text { Turns her sheet around, reads for } \\
24 \text { seconds. Turns to the observer. } \\
\text { "Do squares just mean..." No reac- } \\
\text { tion from the observer. }\end{array}$ & $\begin{array}{l}\text { Turns her sheet around, } \\
\text { reads for } 22 \text { seconds. }\end{array}$ & $\begin{array}{l}\text { M2: control of termi- } \\
\text { nology }\end{array}$ \\
\hline $00: 54$ & "One colour of the area?" & Looks to L. "no." & Refers to black/white \\
\hline $00: 57$ & & $\begin{array}{l}\text { "This can, look, this can be } \\
\text { a square" Points to a } 3 \times 3- \\
\text { square that is build of } 9 \text { little } \\
\text { squares. }\end{array}$ & \\
\hline 01:01 & $\begin{array}{l}\text { "But then, this is ..." } \\
\text { "oh." }\end{array}$ & $\begin{array}{l}\text { "a square. Have a look. } \\
\text { First, we have to count } \\
\text { them." }\end{array}$ & \\
\hline 01:07 & $\begin{array}{l}\text { "We have to detect all of the } \\
\text { squares that exist." }\end{array}$ & "that exist." Looks to $L$. & \\
\hline 01:09 & $\begin{array}{l}\text { Draws lines on her chessboard for } \\
16 \text { seconds. "But, look, this is a } \\
\text { square. But then, this is not." }\end{array}$ & & $\begin{array}{l}\text { M5a: control of the } \\
\text { consistency of the } \\
\text { argumentation }\end{array}$ \\
\hline 01:14 & & $\begin{array}{l}\text { Looks to the observer. "Shall } \\
\text { we write the answer on this } \\
\text { sheet?" } \\
\text { Draws on her sheet for } 4 \\
\text { seconds. } \\
\text { <quiet "Now, we just have } \\
\text { to ..."> }\end{array}$ & \\
\hline $01: 24$ & $\begin{array}{l}\text { Looks at E. "At first, all of the white } \\
\text { ones?" Draws lines on the white } \\
\text { squares. "The black ones are miss- } \\
\text { ing sides, when they belong to the } \\
\text { white ones." }\end{array}$ & & $\begin{array}{l}\text { bP1a: justified single- } \\
\text { step planning }\end{array}$ \\
\hline $01: 32$ & Draws on her sheet for 13 seconds. & $\begin{array}{l}\text { Draws on her sheet for } 13 \\
\text { seconds. }\end{array}$ & \\
\hline $01: 44$ & & $\begin{array}{l}\text { "Just colour the white ones } \\
\text { blue." Laughs, begins to } \\
\text { shade the white squares. }\end{array}$ & \\
\hline 01:48 & $\begin{array}{l}\text { "I wouldn't do that. Because there } \\
\text { are more squares in it." Looks at } \\
\text { E's sheet. }\end{array}$ & & $\begin{array}{l}\text { M4a: control of } \\
\text { methods. } \\
\text { bR3c: reflection of } \\
\text { the markings }\end{array}$ \\
\hline $01: 55$ & & $\begin{array}{l}\text { "Pha!" Laughs. Looks to L. } \\
\text { "Now you said it. Thanks" }\end{array}$ & \\
\hline 01:59 & Laughs. "Doesn't matter." & $\begin{array}{l}\text { "I don't want to...” <unclear } \\
\text { “I don't want to position it.”> }\end{array}$ & \\
\hline
\end{tabular}


Table 5. $L \& E$ - Squares on a Chessboard - excerpt from the transcript, part 2 of 2.

\begin{tabular}{|c|c|c|c|}
\hline time & $\mathrm{L}$ & $\mathrm{E}$ & commentary, codes \\
\hline 02:05 & $\begin{array}{l}\text { Draws borders around the white } \\
\text { squares. }\end{array}$ & $\begin{array}{l}\text { Shades squares for } 8 \\
\text { seconds. }\end{array}$ & (see Figure 1) \\
\hline $02: 11$ & & "Who is faster? Hah." & \\
\hline $02: 13$ & Draws borders around squares. & $\begin{array}{l}\text { Shades squares for } 14 \\
\text { seconds. }\end{array}$ & \\
\hline $02: 26$ & & "Done it!" Laughs, looks at L. & \\
\hline $02: 30$ & $\begin{array}{l}\text { "Then, this one is a square." Draws } \\
\text { a border around the whole board. }\end{array}$ & & \\
\hline $02: 37$ & & $\begin{array}{l}\text { Looks at L's sheet. "The } \\
\text { whole." }\end{array}$ & \\
\hline $02: 40$ & & $\begin{array}{l}\text { Draws a border around the } \\
\text { whole chessboard for } 8 \\
\text { seconds. }\end{array}$ & \\
\hline $02: 45$ & “Hmm, no." & "Did you take that one?" & \\
\hline $02: 48$ & $\begin{array}{l}\text { Draws a thicker line around the } \\
\text { whole chessboard for } 11 \text { seconds. }\end{array}$ & $\begin{array}{l}\text { Draws a thicker line around } \\
\text { the whole chessboard for } 11 \\
\text { seconds. }\end{array}$ & (see Figure 1) \\
\hline $02: 58$ & & $\begin{array}{l}\text { Looks at L's sheet. "That is a } \\
\text { square. And now we have to } \\
\text { count the little black ones. } \\
\text { That could be squares as } \\
\text { well." Draws something for } \\
4 \text { sec. }\end{array}$ & $\begin{array}{l}\text { Pla: single-step } \\
\text { planning }\end{array}$ \\
\hline 03:08 & & $\begin{array}{l}\text { Offers her pen. "Let's } \\
\text { exchange pens, so that we } \\
\text { don't confuse the colours, } \\
\text { okay?" }\end{array}$ & $\begin{array}{l}\text { fP1c: requests the } \\
\text { use of tools }\end{array}$ \\
\hline 03:14 & $\begin{array}{l}\text { "Just take this one." Gives E a } \\
\text { black pen. }\end{array}$ & “Can I?” & \\
\hline 03:18 & & $\begin{array}{l}\text { Takes the pen. "So we don't } \\
\text { confuse the colours." Draws } \\
\text { for } 6 \text { seconds. }\end{array}$ & \\
\hline $03: 28$ & $\begin{array}{l}\text { Draws on her chessboard. "But, } \\
\text { but then, this is (..) I think (.) all of } \\
\text { these are squares." Looks to E. }\end{array}$ & "There could be (..) such a" & $\begin{array}{l}\text { R6a: reflection / } \\
\text { evaluation of an } \\
\text { important situation }\end{array}$ \\
\hline $03: 40$ & & $\begin{array}{l}\text { "So, we just have to. Count } \\
\text { how many there are, so" } \\
\text { Starts to count: <quiet "one, } \\
\text { two, three, four, five> }\end{array}$ & $\begin{array}{l}\text { Pla: single-step } \\
\text { planning: count the } \\
\text { squares }\end{array}$ \\
\hline $03: 47$ & $\begin{array}{l}\text { Counts "one, two, three, seven, } \\
\text { eight" }\end{array}$ & "six, seven, eight." & \\
\hline
\end{tabular}

They start counting and recounting until they decide to write an answer at 07:48:

"64 little, one very big (the whole board), 16 four-part, 4 sixteen-part. Altogether: 85 squares.” 
This was coded as "(2) Basic access" as both girls discovered that there are more than 64 squares, but they only identified squares that fill the chessboard completely without overlapping.

a)

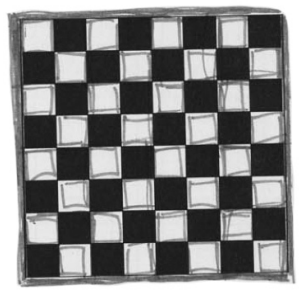

b)

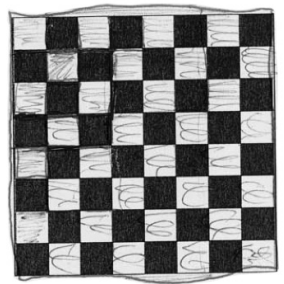

Figure 1. Drawings of L (a) and E (b) - squares on a chessboard.

All of the junctions between the episodes in this process are connected with a metacognitive activity. The following table 6 summarises the activities at those junctions.

Table 6. L \& E-Squares on a Chessboard - episode junctions.

\begin{tabular}{|c|c|c|c|}
\hline time & $\mathrm{L}$ & $\mathrm{E}$ & commentary, codes \\
\hline $\begin{array}{l}(00: 30- \\
00: 50)\end{array}$ & Reading & $\begin{array}{l}\text { Pupils } L \& E \text { read the task } \\
\text { formulation. }\end{array}$ & $\begin{array}{l}\text { The Reading ends with a question } \\
\text { by } L \text { that was coded as monitoring } \\
\text { (M2). }\end{array}$ \\
\hline $\begin{array}{l}(00: 50- \\
01: 30)\end{array}$ & Analysis & $\begin{array}{l}\text { They struggle with the task } \\
\text { formulation and try to make } \\
\text { sense of it. }\end{array}$ & $\begin{array}{l}\text { The last statement of the Analysis } \\
\text { that leads to the following Explora- } \\
\text { tion is justified planning (bPla). }\end{array}$ \\
\hline $\begin{array}{l}(01: 30- \\
03: 30)\end{array}$ & Exploration & $\begin{array}{l}\text { They try some unstructured } \\
\text { ideas like shading the } \\
\text { squares or drawing boarders } \\
\text { around the white ones. }\end{array}$ & $\begin{array}{l}\text { The Exploration ends with the } \\
\text { finding that there are more than the } \\
\text { little ( } 1 \times 1) \text { squares, which is a reflec- } \\
\text { tion (R6a). } \\
\text { The new episode starts with plan- } \\
\text { ning (P1a). }\end{array}$ \\
\hline $\begin{array}{l}(03: 30- \\
07: 50)\end{array}$ & $\begin{array}{l}\text { Planning- } \\
\text { Implementation }\end{array}$ & $\begin{array}{l}\text { In a structured way, they try } \\
\text { to count the squares (with- } \\
\text { out realising all of them). }\end{array}$ & $\begin{array}{l}\text { This combined episode of Planning- } \\
\text { Implementation ends with drawing } \\
\text { an interim balance (R6a). }\end{array}$ \\
\hline $\begin{array}{l}(07: 50- \\
08: 10)\end{array}$ & Writing & $\begin{array}{l}\text { They write down the results } \\
\text { without new ideas. }\end{array}$ & $-\cdots$ \\
\hline
\end{tabular}

